\author{
Federal Reserve Bank of New York \\ Staff Reports
}

\title{
Direct Purchases of U.S. Treasury Securities by Federal Reserve Banks
}

\author{
Kenneth D. Garbade
}

Staff Report No. 684

August 2014

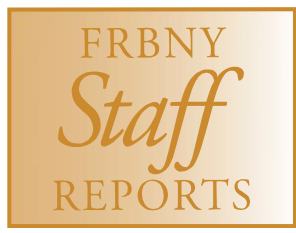

This paper presents preliminary findings and is being distributed to economists and other interested readers solely to stimulate discussion and elicit comments. The views expressed in this paper are those of the author and do not necessarily reflect the position of the Federal Reserve Bank of New York or the Federal Reserve System. Any errors or omissions are the responsibility of the author. 


\title{
Direct Purchases of U.S. Treasury Securities by Federal Reserve Banks
}

Kenneth D. Garbade

Federal Reserve Bank of New York Staff Reports, no. 684

August 2014

JEL classification: E58, H62, H63

\begin{abstract}
Until 1935, Federal Reserve Banks from time to time purchased short-term securities directly from the United States Treasury to facilitate Treasury cash management operations. The authority to undertake such purchases provided a robust safety net that ensured Treasury could meet its obligations even in the event of an unforeseen depletion of its cash balances. Congress prohibited direct purchases in 1935, but subsequently provided a limited wartime exemption in 1942. The exemption was renewed from time to time following the conclusion of the war but ultimately was allowed to expire in 1981. This paper addresses three questions: 1) Why did Congress prohibit direct purchases in 1935 after they had been utilized without incident for eighteen years, 2) why did Congress provide a limited exemption in 1942 instead of simply removing the prohibition, and 3) why did Congress allow the exemption to expire in 1981 ?
\end{abstract}

Key words: Treasury debt issuance, Federal Reserve, direct purchases

Garbade: Federal Reserve Bank of New York (e-mail: kenneth.garbade@ny.frb.org). The views expressed in this paper are those of the author and do not necessarily reflect the position of the Federal Reserve Bank of New York or the Federal Reserve System. 
From time to time, U.S. Treasury officials have questioned whether the Treasury should have a safety net that would allow it to continue to meet its obligations even in the event of an unforeseen depletion of its cash balances. ${ }^{1}$ The original version of the Federal Reserve Act provided a robust safety net because the act implicitly authorized the new Reserve Banks to buy securities directly from the Treasury. The Banks made active use of their "direct purchase authority" during, and for a decade and a half after, World War I. Congress acted to prohibit direct purchases in 1935, but reversed course and provided a limited wartime exemption in 1942. The exemption was renewed from time to time following the conclusion of the war but ultimately allowed to expire in 1981.

This paper addresses three questions: (1) why did Congress prohibit direct purchases in 1935 (after they had been utilized without incident for eighteen years), (2) why did Congress provide a limited exemption in 1942 (instead of simply removing the prohibition), and (3) why did Congress allow the exemption to expire in 1981 ?

\section{Authority for Direct Purchases Provided by the Federal Reserve Act}

The first sentence of Section 14 of the Federal Reserve Act provided that "any Federal Reserve bank may, under rules and regulations prescribed by the Federal Reserve Board, purchase and sell in the open market, ... cable transfers and bankers acceptances and bills of exchange of the kinds and maturities by this Act made eligible for rediscount ..." (Emphasis added.) Subsection (b) further provided that every Reserve Bank was authorized "to buy and sell, at home or abroad, bonds and notes of the United States ..."

1 Treasury officials most recently raised the issue in the April 2014 meeting of the Treasury Borrowing Advisory Committee. Depleted cash balances can arise from an unanticipated revenue shortfall or spike in disbursements (such as happened on April 23, 1986), an inability to access credit markets on a timely basis (such as happened on September 11, 2001, when an auction of 4-week bills was cancelled), or an auction failure (such as happened in an offering of 20-year bonds in August 1973). 
The key distinction between the first sentence of section 14 and subsection (b) is that instruments eligible for discount could be bought and sold only in the open market; purchases and sales of Treasury securities were not similarly limited. A memorandum prepared in response to an inquiry from the House Banking Committee about the source of the Fed's authority to purchase securities directly from the Treasury stated that,

No question was ever raised as to the authority of the Federal Reserve banks, under the provisions of subsection (b) ..., to buy United States bonds directly from the Treasury. The contrasting provisions of [the first sentence of] section 14 and subsection (b) would seem to supply ample legal justification for this fact. Under section 14 Federal Reserve banks could purchase and sell eligible paper only "in the open market"; but their power under subsection (b) to deal in Government bonds was not so limited. Accordingly, the Board at all times assumed that the Federal Reserve Banks had the legal authority to purchase Government bonds directly from the Treasury ...2

\section{Usage Prior to 1935}

The first use of the direct purchase authority came in March 1917, when the Reserve Banks, quite reluctantly, bought $\$ 50$ million of certificates of indebtedness directly from the Treasury. ${ }^{3}$

On March 28, 1917, Treasury Secretary William McAdoo advised the Federal Reserve Board that he was interested in borrowing funds for three months at an interest rate of 2 percent per annum. He suggested that,

This is an excellent opportunity for the Federal Reserve Banks to secure a desirable short-time investment and to demonstrate their usefulness as fiscal agents of the Government. I propose, therefore, to offer the Federal Reserve Banks, the opportunity to take these certificates. Will you please get in touch with the Federal Reserve Banks and ascertain whether or not they care to take this loan and what amount they respectively desire to take? ${ }^{4}$

2 Committee on Banking and Currency (March 3, 4, and 5, 1947, p. 120).

3 Garbade (2012, pp. 131-133).

4 Quoted in Harding (1925, pp. 87-88). 
The country being on the verge of war (President Wilson signed a declaration of war on April 6), the Banks agreed to take the certificates, but they weren't happy about it. The 2 percent interest rate was below market rates ${ }^{5}$ and the Banks felt the loan was an inappropriate use of Federal Reserve resources. The Governor of the Federal Reserve Bank of Boston observed that,

[W]e should have preferred, had the taking of this issue by member banks been burdensome to them, to have rediscounted for them to meet their requirements, rather than to have taken the issue direct, and our committee are in hopes that should future financing of this sort become necessary that it will be dealt with in this way, and the loans placed at a rate that will induce the commercial banks to absorb the issue. ${ }^{6}$

The Directors of the Federal Reserve Bank of New York observed similarly that,

Whenever in the future circumstances may seem to indicate the advisability of any action being taken by the Bank as Fiscal Agent [the directors of the Federal Reserve Bank of New York] look forward to such consultation with the Government relative thereto as is customary between fiscal agents and their principals, in order to be in a position to render it the most effective service. ... [The directors] are strongly of the opinion that the normal services of the Bank as fiscal agent will best be rendered by assisting in distributing Government securities rather than by acting as a purchaser of them. ... The Directors desire, therefore, that their present action ... should not be considered as establishing a precedent or a policy which will necessarily be followed in the future. ${ }^{7}$

5 Contemporaneous as well as later observers remarked on the 2 percent interest rate. See "Reserve Banks Lend M'Adoo \$50,000,000," New York Times, March 29, 1917, p. 2 (bankers characterized as believing that "other institutions ... would not care to invest their funds ... at the very unattractive rate"), "Federal Reserve Banks Used by Government," Wall Street Journal, March 30, 1917, p. 8 (stating that McAdoo "could not hope to place [the certificates] in the market" at 2 percent), Harding (1925, p. 88, "The opinion of a majority of the members of the Federal Reserve Board, and of all of the Federal Reserve Bank Governors, was that the rate proposed ... was too much below the market, and that it should have been at least two and one half per cent."), and Chandler (1958, p. 113, "The 2 percent rate was well below market and unattractive to private buyers.").

6 Quoted in Chandler (1958, pp. 113-114).

7 Quoted in Chandler (1958, p. 114). 
The Treasury did not subsequently obtain any term credit directly from the Reserve Banks, but it did obtain a series of short-term "cash management" loans. ${ }^{8}$ All of the loans were represented by certificates of indebtedness issued directly to the Banks. As illustrated in Table 1, most were for five days or less, although several ran for more than two weeks.

Until 1935, the Treasury continued to borrow directly from Federal Reserve Banks for cash management purposes as circumstances warranted. ${ }^{9}$ The borrowings were sometimes relatively infrequent, as in 1926 (Table 2), and sometimes more frequent, as in 1927 (Table 3). ${ }^{10}$

\section{The 1935 Prohibition}

Section 206(a) of the Banking Act of August 23, 1935, added a significant proviso to section 14(b) of the Federal Reserve Act:

Provided, That any bonds, notes, or other obligations which are direct obligations of the United States or which are fully guaranteed by the United States as to principal and interest may be bought and sold without regard to maturities but only in the open market." (Emphasis added.)

The proviso explicitly prohibited direct purchases of Treasury securities by Federal Reserve Banks.

8 The wartime cash management loans are noted in Hollander (1919, p. 25), Hendricks (1933, p. 272), 1918 Treasury Annual Report, pp. 24 and 27, 1919 Treasury Annual Report, pp. 55 and 260, 1917 Federal Reserve Board Annual Report, p. 265, 1918 Federal Reserve Board Annual Report, p. 274, 1917 Federal Reserve Bank of New York Annual Report, p. 60, 1918 Federal Reserve Bank of New York Annual Report, p. 13, and 1919 Federal Reserve Bank of New York Annual Report, pp. 16 and 65.

9 Direct issuance of Treasury certificates of indebtedness to Federal Reserve Banks after World War I is reported in 1924 Federal Reserve Board Annual Report, p. 98, 1926 Federal Reserve Board Annual Report, p. 116, 1929 Federal Reserve Board Annual report, p. 71, 1931 Federal Reserve Board Annual report, p. 54, and 1933 Federal Reserve Board Annual Report, p. 117.

10 Treasury borrowed almost continually from the Federal Reserve during the fall of 1927, a period when it was actively engaged in retiring the Second Liberty Loan. Garbade (2012, pp. 172-178). 


\section{Origin of the Prohibition}

The Banking Act of 1935 was introduced into the $74^{\text {th }}$ Congress as H.R. 7617. Section 207 of that bill would have amended the Federal Reserve Act by adding a proviso to Section 14(b) allowing the Reserve Banks to buy obligations fully guaranteed by the United States as well as direct obligations of the government:

Provided, That any bonds, notes, or other obligations which are direct obligations of the United States or which are fully guaranteed by the United States as to principal and interest may be bought and sold without regard to maturities. ${ }^{11}$

As the House Banking Committee observed, "There is no logic in discriminating against obligations which, being in effect obligations of the United States Government, differ from other such obligations only in that they are not issued directly by the Government." 12

Following passage by the House of Representatives, H.R. 7617 moved to the Senate, where it was referred to the Senate Banking Committee. That committee reported out an amended version of the bill that included the ultimately adopted proviso prohibiting direct purchases of Treasury securities by Federal Reserve Banks. The committee report did not explain the reason for the prohibition, stating only that "Section 207 of the bill as it passed the House ... has been modified ... so as to provide that direct [and guaranteed] obligations of the United States ... may be purchased only in the open market." 13

Treasury officials were not happy with the Senate version of H.R. 7617. In a letter to the chairman of the Senate Banking Committee, Under Secretary of the Treasury T. J. Coolidge questioned "whether in times of emergency it might not be important to permit a direct loan. This might have been the case in the bank holiday in 1933 had there been a sizeable note issue

11 Committee on Banking and Currency (April 19, 1935, p. 59).

12 Committee on Banking and Currency (April 19, 1935, pp. 11-12).

13 Committee on Banking and Currency (May 13, 1935, p. 13). 
coming due when the banks were closed; it might be the case in time of war." 14 Despite Treasury's objections, the Conference Committee chose to retain the Senate version of the proviso ${ }^{15}$ and the prohibition passed into law.

\section{Why Did Congress Prohibit Direct Purchases in 1935?}

There is no clear answer to the question of why Congress prohibited direct purchases in 1935. Several possibilities have been mooted.

Marriner Eccles, Chairman of the Board of Governors of the Federal Reserve System, suggested in 1942 that direct purchases may have been prohibited to prevent excessive government expenditures,

The restriction forbidding Federal Reserve banks to buy Government obligations except on the open market was imposed ... on the theory that forcing the Government to borrow on the open market would afford a check on excessive public expenditures ${ }^{16}$

and relatedly suggested in 1947 that the prohibition was aimed at preventing chronic deficits,

Those who inserted this proviso were motivated by the mistaken theory that it would help to prevent deficit financing. According to the theory, Government borrowing should be subject to the "test of the market." 17

[T]here was a feeling that [the absence of a prohibition] left the door wide open to the Government to borrow directly from the Federal Reserve bank all that was necessary to finance the Government deficit, and that took off any restraint toward getting a balanced budget. ${ }^{18}$

14 Letter from Coolidge to Carter Glass, July 30, 1935, Box 46D, Carter Glass papers at the University of Virginia.

15 Committee of Conference (1935, pp. 50-51).

16 Committee on the Judiciary (January 30 and February 2, 1942, pp. III and 44-45).

17 Committee on Banking and Currency (March 3, 4, and 5, 1947, p. 2).

18 Committee on Banking and Currency (March 3, 4, and 5, 1947, p. 8). 
[T] here was some feeling that [Congress] ought to give the money market more control and influence over what money the Government was going to be able to raise, and that if they stopped the open-market committee from purchasing directly from the Treasury they would thereby deter deficit financing. ${ }^{19}$

More idiosyncratic views were sometimes expressed in private communications. In 1947, W. Randolph Burgess, a former Manager of the System Open Market Account and a former Vice Chairman of the National City Bank of New York, stated his belief that the prohibition was aimed at limiting the expansion of Federal Reserve Bank balance sheets:

One reason for the prohibition of direct purchases in the Banking Act of 1935 was that the Glass Bill of 1932 had thrown the door wide open for the purchase of Government securities. The two things went together. ${ }^{20}$

and Eccles asserted that the prohibition was inserted at the behest of Government securities dealers:

... authority [to purchase directly from the Treasury] was taken away from the Reserve System primarily at the instance of some of the dealers ... ${ }^{21}$

I think the real reasons for writing the prohibition into the [Banking Act of 1935] ... can be traced to certain Government bond dealers who quite naturally had their eyes on business that might be lost to them if direct purchasing were permitted. ${ }^{22}$

Since the Reserve Banks retained the authority to buy Treasury securities in the open market, the idea of limiting expenditures, deficits, or Reserve Bank balance sheets by prohibiting

19 Committee on Banking and Currency (March 3, 4, and 5, 1947, p. 121).

20 Letter from Burgess to Jesse Wolcott, Chairman of the House Banking Committee, March 27, 1947. FRASER, The Marriner S. Eccles Document Collection. The Banking Act of 1932 provided, for the first time, that Federal Reserve notes could be backed by Treasury securities as well as by gold and commercial paper.

21 Letter from Eccles to R.C. Morris, Vice President of Bankers Trust Company and Chairman of the Government Security Dealer Group, March 27, 1947. FRASER, The Marriner S. Eccles Document Collection.

22 Letter from Eccles to Wolcott, April 3, 1947. FRASER, The Marriner S. Eccles Document Collection. 
direct purchases was clearly fallacious. Dealer resistance to direct purchases seems unlikely because the Fed had, since the March 1917 imbroglio, limited the use of its direct purchase authority to very-short-term securities.

\section{Relaxing the Prohibition in 1942}

The United States was at war with Germany as well as Japan within days after the attack on Pearl Harbor. It was clear that the war, already in its third year in Europe, would be lengthy and expensive. Treasury would have to borrow huge sums of money, so Congress raised the debt ceiling from $\$ 65$ billion to $\$ 125$ billion. ${ }^{23}$ Settling a large war loan drive was liable to strain the money markets, so Congress also relaxed, for the duration of the war, the prohibition against direct purchases of Treasury debt. ${ }^{24}$

The initial proposal for relaxing the prohibition against direct purchases was simply to delete the words "but only in the open market" from the proviso that had been added to section 14(b) by the Banking Act of $1935 .^{25}$ However, the action ultimately taken was more nuanced, and served to restrain an aggressive use of direct purchases contemplated by Chairman Eccles.

\section{What Eccles Contemplated}

Written testimony submitted by Eccles to the House Judiciary Committee in 1942 can be read as contemplating a cash management function for direct purchases that was little more than a modest extension of the use of direct purchases prior to 1935 :

This is a power ... that the Federal Reserve banks ought to have in order to enable them to aid the Treasury in meeting emergencies which may arise during the war ... It would enable the Federal Reserve banks to tide the Treasury over a period, such as that following the attack at Pearl Harbor, and thus avoid the necessity of having the Treasury offer Government obligations for sale on the open market at a time when the

23 Public Debt Act of March 28, 1942.

24 Section 401 of the Second War Powers Act of March 27, 1942.

25 Committee on the Judiciary (January 19, 1942, p. 3). 
market is demoralized and an additional public offering might add to the confusion and demoralization of the market and do incalculable harm to the Government's credit and to the holders of outstanding Government obligations. ${ }^{26}$

Rather than being forced to access the credit markets at a time when the markets were "demoralized," the Treasury could call on the Fed to provide temporary financing until a more propitious time.

However, Eccles oral testimony suggests that he actually contemplated a far more expansive role, that the Fed might underwrite Treasury debt:

If the market situation happens to be unfavorable on any given day when a financing operation is up ... the Federal Reserve System should be in a position where it can take care of it by a direct purchase from the Treasury of an issue of securities. That does not mean that the Federal Reserve System would hold indefinitely securities that are so purchased. It may purchase a block of securities at a given time and then sell them in the market at such time as the market may be favorable. ${ }^{27}$

It might be that the market would be such that it would be difficult to float the necessary amount of securities at a particular time, in which case the Federal Reserve could take a portion of such securities and, later, could sell those securities. In that case the Federal Reserve would attempt to redistribute those securities. It would underwrite an issue and undertake to redistribute it when the market was favorable. ${ }^{28}$

Eccles justified this unprecedented activity on the need for a stable Treasury market and, ultimately, on Treasury's need to finance the war unrestrained by the credit markets:

If the market is not prepared or willing to take the Treasury financing, the Treasury should not be put in a position ... where it cannot do its necessary financing on a basis that is in line with what the Treasury has been financing on. In other words, it would be unfortunate for the rates on Government financing in a war period to be advancing all the time constantly. We need a stable financing. ... We feel it is absolutely essential that the Government security market be stabilized ... Without this, the Treasury requiring money may have to pay what the market dictates to it. ${ }^{29}$

26 Committee on the Judiciary (January 30 and February 2, 1942, pp. III and 44-45).

27 Committee on the Judiciary (January 30 and February 2, 1942, p. 47).

28 Committee on the Judiciary (January 30 and February 2, 1942, p. 48).

29 Committee on the Judiciary (January 30 and February 2, 1942, pp. 49-50). 
It is designed to assure the Treasury of its needed financing without any hampering, without the Treasury being dictated to, in a sense, by the market. In a war economy the markets for practically everything are controlled; your commodity markets are controlled; you have price controls. It certainly would seem to us that the Treasury with the assistance of the Federal Reserve System should be in a position, likewise, to exercise some control in the money market situation. ${ }^{30}$

\section{The Amended Proviso}

In the end, Congress chose not to restore unfettered authority for the Fed to purchase Treasury securities directly, but rather amended the proviso to section 14(b) to provide an exemption capped at $\$ 5$ billion:

Provided, That any bonds, notes, or other obligations which are direct obligations of the United States or which are fully guaranteed by the United States as to principal and interest may be bought and sold without regard to maturities either in the open market or directly from or to the United States; but all such purchases and sales shall be made in accordance with the provisions of Section 12A of this Act and the aggregate amount of such obligations acquired directly from the United States which is held at any one time by the twelve Federal Reserve banks shall not exceed $\$ 5,000,000,000$. (Emphasis added.)

The $\$ 5$ billion cap limited how much the Fed could underwrite at any one time and precluded any significant accumulation of underwriting commitments.

\section{Wartime Usage}

The first several lines of Table 4 summarize Treasury borrowings from Federal Reserve Banks pursuant to the $\$ 5$ billion exemption during World War II. ${ }^{31}$ Eccles has described how the exemption facilitated an efficient use of Treasury cash balances around tax collection dates:

30 Committee on the Judiciary (January 30 and February 2, 1942, p. 48).

31 For tenors and amounts of Treasury borrowings from Federal Reserve Banks on a day-byday basis during World War II, see 1942 Board of Governors Annual Report, p. 16, 1943 Board of Governors Annual Report, p. 67, and 1949 Board of Governors Annual Report, p. 85. 
The temporary [borrowings] did not mean that the Treasury had no funds. It had large deposits in war-loan accounts with commercial banks at all these periods. Sufficient funds could have been transferred from the war loan accounts to the Federal Reserve banks to cover all expenditures. However, transfer of funds from the commercial banks to the Federal Reserve banks for this purpose would have left the Treasury, after the tax receipts had come in, with a much larger balance at the Reserve banks than it needed and this would have unduly reduced bank reserves for an extended period.

If commercial banks are faced at tax periods not only with deposit withdrawals to meet tax payments but also with drains on their war loan accounts, they would have to follow one of four courses: If they had sufficient excess reserves with the Federal Reserve banks, they could reduce their excess balances to the extent necessary. If they did not have excess reserves - this normally is the case - they would have to sell sufficient securities to obtain the funds, or they could withdraw correspondent balances. That means from the correspondent banks, and those banks in turn would have to sell securities to meet the withdrawals - or they would have to borrow from the Reserve banks. All of these alternatives would tend to tighten money market conditions at a time when taxpayers would be drawing on their bank accounts to make their tax payments. In other words, if the Treasury could not borrow from the Federal Reserve banks by what is, in effect, an overdraft at these tax payment periods, and in this way avoid withdrawals from its war loan accounts to pay off maturing obligations, money conditions would unduly tighten and tend to [destabilize] the money market and the Government securities market. ${ }^{32}$

The 1942 Annual Report of the Board of Governors similarly took note of the use of direct purchases by Federal Reserve Banks "to supply funds to the Treasury pending receipts from taxes or new issues of securities." 33

\section{Extending the Exemption}

Following the conclusion of World War II, Congress contemplated making the $\$ 5$ billion exemption permanent. In testimony before the House Banking Committee in 1947, Eccles recalled the utility of the exemption during the war:

The purpose for which the direct-purchase authority has always been used in the past and would be used in the future is simply one of meeting the temporary needs of the Treasury which, if met in other ways, would entail either needless additional costs in

32 Committee on Banking and Currency (March 3, 4, and 5, 1947, pp. 3-4).

331942 Board of Governors Annual Report, p. 16. 
managing the public debt or equally needless fluctuation in the securities and money markets for brief periods. What is involved in the proposed bill is not a question of monetary theory or policy, but simply a question of efficient, economical, and business-like management of the public debt.

The direct-purchase authority is, in effect, merely an overdraft privilege with the Reserve banks - a line of available credit for use if needed. Without it, the Treasury would feel obliged to carry much larger cash balances, which means that it would have to borrow more and thereby increase the amount and cost of the public debt. ${ }^{34}$

Eccles argued that the same would continue to be true in the future,

[T] he authority ... is more needed than ever today, because of the size of our debt and the refinancing operations. The fact that tax collections are also very large, currently about $\$ 40,000,000,000$ a year, means that quarterly withdrawals from the banking system are going to continue to be heavy, so that it will be desirable to have the overdraft authority to help in stabilizing the money market at tax dates. ${ }^{35}$

The House Banking Committee agreed with Eccles as to the benefits of the exemption,

By providing this line of credit the Treasury has a source to which it may turn to obtain funds in a substantial amount on little notice to meet temporary situations and contingencies. With such an emergency source of funds, it is possible for the Treasury to operate with a smaller cash balance than might otherwise be necessary, thus resulting in a saving of interest. ${ }^{36}$

Furthermore, direct buying provides a flexible method of easing the money market in periods of heavy drain as, for example, around income-tax dates. By borrowing funds from the Federal Reserve banks and expending them prior to tax dates, the Treasury can put the funds into the market; and, as taxes are received, such special borrowings are reduced and some retired. In this connection the direct purchase authority provides for efficient and businesslike management of the public debt. ${ }^{37}$

Nevertheless, the committee did not believe that making the exemption permanent was "advisable." Instead, the committee provided for an extension of the exemption until June 30,

34 Committee on Banking and Currency (March 3, 4, and 5, 1947, p. 3).

35 Committee on Banking and Currency (March 3, 4, and 5, 1947, p. 4).

36 Committee on Banking and Currency (March 10, 1947, pp. 1-2).

37 Committee on Banking and Currency (March 10, 1947, p. 2). 
1950, suggesting that "Congress could at that time review the necessity for its continuance for a longer period if such might be its desire and conditions so warranted." 38 The Act of April 28, 1947, amended the proviso to section 14(b) of the Federal Reserve Act accordingly:

Provided, That, notwithstanding any other provision of this Act,

(1) until July 1, 1950, any bonds, notes, or other obligations which are direct obligations of the United States or which are full guaranteed by the United States as to principal and interest may be bought and sold without regard to maturities either in the open market or directly from or to the United States; but ... the aggregate amount of such obligations acquired directly from the United States which is held at any one time by the twelve Federal Reserve banks shall not exceed \$5,000,000,000; and

(2) after June 30, 1950, any bonds, notes, or other obligations which are direct obligations of the United States or which are fully guaranteed by the United States as to principal and interest may be bought and sold without regard to maturities but only in the open market.

The exemption was thereafter renewed from time to time until 1981.

Table 4 summarizes direct purchases pursuant to the $\$ 5$ billion exemption following the end of World War II. ${ }^{39}$ Direct purchases were hardly used in the second half of the 1940s, became more frequent during the Korean War, and then declined again until the late 1960s. For reasons discussed below, there have been no direct purchases since April 1979.

\section{Two Innovations in Treasury Cash Management}

Two innovations in Treasury cash management in the mid-1970s - short-term cash management bills and payment of interest on Treasury Tax and Loan accounts at commercial banks - had important consequences for the ultimate fate of the direct purchase exemption.

38 Committee on Banking and Currency (March 10, 1947, p. 3).

39 For tenors and amounts of Treasury borrowings from Federal Reserve Banks on a day-byday basis after World War II, see 1953 Board of Governors Annual Report, p. 65, 1967 Board of Governors Annual Report, p. 355, 1972 Board of Governors Annual Report, p. 235, and 1981 Board of Governors Annual Report, p. 221. 
Treasury, like most households and corporations, holds cash to buffer fluctuations in its receipts and expenditures. In the 1960s and 1970s, Treasury cash balances varied cyclically within a month due to relatively heavier disbursements in the first half of a month (primarily Social Security payments) and relatively heavier receipts in the second half (primarily personal and corporate income taxes). To accommodate the intra-monthly variation, Treasury started most months with a large cash balance, ran it down over the first half of the month, and then rebuilt it over the second half.

Prior to 1972, Treasury kept the bulk of its cash in Treasury Tax and Loan accounts and a modest balance in accounts at Federal Reserve Banks. It disbursed funds from its Reserve Bank accounts and, when necessary, replenished those accounts with transfers from its TT\&L accounts.

TT\&L deposits did not earn interest. A study published in 1974 indicated that, in 1972, Treasury's cash management practices cost the Treasury more than $\$ 250$ million in foregone interest (net of the value of services performed without charge by TT\&L banks). ${ }^{40}$ As a result, Treasury officials decided to shift a significant portion of their cash balances to Federal Reserve Banks. To offset the drain of reserves from the banking system, the Fed would have to buy Treasury securities, thus adding to its earning assets. The increase in earning assets would augment its repatriations to Treasury, thereby providing Treasury with implicit interest income.

Given the intra-month variation in aggregate Treasury cash balances, the new cash management strategy led, inevitably, to increased intra-month variation in Treasury balances at the Fed. The increased variation created a need for more frequent open market operations drains when Treasury balances at the Fed were declining (and adding reserves to the banking system), additions when Treasury balances at the Fed were rising (and draining reserves from the

\footnotetext{
40 Report on a Study of Tax and Loan Accounts, Department of the Treasury, 1974.
} 
banking system). The increased volume of operations complicated the conduct of monetary policy. $^{41}$

There were two ways to mitigate the problem. First, Treasury could require payment of interest on TT\&L deposits, allowing it to go back to the pre-1972 regime and to maintain no more than a small, but stable, balance at Federal Reserve Banks. However, commercial banks could not pay interest on TT\&L accounts in the absence of new statutory authority - a lengthy process.

Alternatively (or additionally), Treasury could issue short-dated "cash management" bills to the public in the first half of a month, for redemption in the second half of a month, thereby borrowing from the public rather than relying on balances at Federal Reserve Banks. This option did not require any new statutory authority.

\section{Short-term Cash Management Bills}

Short-term cash management bills were introduced in August 1975. The first offering was for $\$ 1$ billion, announced Wednesday, August 6, auctioned on August 7, and issued on August 8, to mature 18 days later, on Tuesday, August 26. ${ }^{42}$ Ed Yeo, Under Secretary of the Treasury for Monetary Affairs, stated that the new bills were designed specifically to reduce the frequency of open market operations. ${ }^{43}$

The second and third short-term cash management bills were offered in September 1975 a total of $\$ 1.5$ billion of 13 - and 20-day bills. In announcing the offerings, Treasury stated that the need for cash management instruments "has substantially increased over the past several years and is a result of the growing concentration of large payments in the first several working

41 Brockschmidt (1975), McDonough (1976), and Lovett (1978).

42 The bill was a reopening of an old year bill. Year bills at that time were issued on a Tuesday and matured 52 weeks later, on a Tuesday.

43 “18-Day Bill Planned to Help Keep Pace with Spending," New York Times, August 7, 1975, p. 55 . 
days of each month" and observed that "use of short-dated [cash management bills] represents a new means for the maintenance of orderly markets." ${ }^{44}$ Ralph Forbes, Special Assistant to the Secretary for Debt Management, said that officials were "very pleased with the results." 45

Issuance of short-term cash management bills continued on an "as-needed" basis through the balance of the 1970s (Table 5). Every bill was issued in the first half of a month and matured in the second half of a month.

\section{Interest-Bearing TT\&L Balances}

The Act of October 28, 1977, authorized the Secretary of the Treasury, "for cash management purposes, to invest any portion of the Treasury's operating cash for periods up to ninety days in (1) obligations of depositaries maintaining Treasury tax and loan accounts secured by a pledge of collateral acceptable to the Secretary of the Treasury as security for tax and loan accounts ..." The act further provided that "investments in obligations of depositaries maintaining such accounts shall be made at rates of interest prescribed by the Secretary of the Treasury, after taking into consideration prevailing market rates of interest."

The new cash management program went into effect on November 2, $1978 .^{46}$ The interest rate on TT\&L deposits was set at the weekly average effective Federal funds rate published by the Federal Reserve, less 25 basis points, a rate that was, at the time, approximately equal to the rate on overnight repurchase agreements.

44 "Treasury to Sell Short-Term Bills," New York Times, September 4, 1975, p. 49. See similarly, "Treasury Will Offer 13-Day, 20-Day Bills Valued at \$1.5 Billion," Wall Street Journal, September 4, 1975, p. 19.

45 “Congress Asked to Allow Up to 10-Year Terms," New York Times, September 30, 1975, p. 51.

46 Federal Reserve Bank of New York Circular no. 8452, "Implementation of New Treasury Tax and Loan Investment Program,” November 9, 1978. See also Lovett (1978) and Lang (1979). 


\section{Termination of the Exemption}

In early 1978, the most recent renewal of the $\$ 5$ billion exemption to the prohibition of direct purchases was due to expire at the end of April. ${ }^{47}$ In anticipation of renewing the exemption for another year, the Subcommittee on Domestic Monetary Policy of the House Banking Committee held a hearing on April 5, 1978. ${ }^{48}$ Renewal was supported by both Treasury and Federal Reserve officials; subcommittee chairman Parren Mitchell remarked that prompt action to renew "would appear to be in the public interest" 49

During an abbreviated hearing, three recent developments were noted:

- the introduction of short-term cash management bills that gave Treasury access to short-term credit and could be announced, auctioned, and issued in as little as two or three days, ${ }^{50}$

- the recently authorized (but not yet implemented) change in the TT\&L system that would allow Treasury to maintain larger cash balances without complicating the conduct of monetary policy by the Fed, ${ }^{51}$ and

- the fact that Treasury had recently used the $\$ 5$ billion exemption to borrow $\$ 2 \frac{1}{2}$ billion directly from the Federal Reserve in anticipation of an imminent reduction in the debt ceiling. ${ }^{52}$

The first two items raised the possibility that the $\$ 5$ billion exemption was no longer needed, that the introduction of short-term cash management bills and interest on TT\&L deposits had

47 As provided by the Act of November 7, 1977.

48 Committee on Banking, Finance and Urban Affairs (April 5, 1978).

49 Committee on Banking, Finance and Urban Affairs (April 5, 1978, pp. 1-3).

50 Committee on Banking, Finance and Urban Affairs (April 5, 1978, p. 3, testimony of Paul Taylor, Deputy Fiscal Assistant Secretary of the Treasury).

51 Committee on Banking, Finance and Urban Affairs (April 5, 1978, p. 5).

52 Committee on Banking, Finance and Urban Affairs (April 5, 1978, pp. 6-7, testimony of Assistant Secretary of the Treasury Paul Taylor). 
rendered direct purchase of Treasury securities by the Fed superfluous. The third item demonstrated that Treasury was liable to resort to direct issuance in circumstances and for reasons not previously contemplated. All three developments were explored more fully during a second hearing in June $1978,{ }^{53}$ and, following renewal of the exemption to April 30, 1979, in another round of hearings in March 1979. ${ }^{54}$

\section{Short-term Cash Management Bills}

Short-term cash management bills were an obvious alternative source of short-term funding. J. Charles Partee, a member of the Board of Governors, observed in the June 1978 hearing that "the frequency of direct borrowing [in anticipation of receipt of tax revenues] has been reduced significantly with the introduction of short-dated cash-management bills" 55 and that “in recent years, the Treasury's need to offset cash drains just before tax payment dates has been met principally by means of cash management bills." 56 Partee repeated his observation in March 1979, stating that "the direct borrowing authority ... has come to be used only infrequently" because "the Treasury now often relies on short-dated cash management bills to cover low points in its cash balance prior to key income tax payment dates." 57

Nevertheless, Partee resisted the notion that cash management bills obviated the need for direct lending. He noted that issuance of cash management bills required "a few days" notice, while a direct loan could be arranged "immediately." 58 Additionally, of course, issuance of cash

53 Committee on Banking, Finance and Urban Affairs (June 27 and 28, 1978).

54 Committee on Banking, Finance and Urban Affairs (March 5, 1979).

55 Committee on Banking, Finance and Urban Affairs (June 27 and 28, 1978, p. 7).

56 Committee on Banking, Finance and Urban Affairs (June 27 and 28, 1978, p. 8).

57 Committee on Banking, Finance and Urban Affairs (March 5, 1979, p. 7).

58 Committee on Banking, Finance and Urban Affairs (March 5, 1979, p. 8, noting that "since Treasury cash management bills can be announced, offered, and delivered within a few days under present debt management procedures, what the Treasury appears to us to need in addition is a backstop facility that permits it to acquire a sizable volume of funds immediately without resort to the market," emphasis added). 
management bills required that the markets were open and functioning - an assumption that was later challenged by the terrorist attacks on September 11, 2001, when Treasury had to cancel a 4week bill auction, and by the disorderly market conditions on August 21, 2007, when an auction offering of 4-week bills very nearly failed. ${ }^{59}$

\section{TT\&L Balances}

A larger balance in TT\&L accounts was another obvious source of short-term funding. In the June 1978 hearing, Subcommittee Chairman Mitchell noted that "we now have the new tax and loan procedures," and wondered "why would you need this draw authority from the standpoint of cash management once those new procedures go into effect?" 60 Assistant Secretary of the Treasury Roger Altman replied that the flexibility of direct borrowing "is not provided by the tax and loan account system," 61 noting that calling for funds from TT\&L accounts, like issuing cash management bills, generally required several days' notice.

\section{Borrowing in Anticipation of a Debt Ceiling Constraint}

The matter of Treasury borrowing directly from the Federal Reserve in anticipation of a debt ceiling constraint rubbed at least a few Congressmen the wrong way. Treasury resorted to such borrowing in September $1977{ }^{62}$ and again in March 1979. ${ }^{63}$ The motivation for those

59 See similarly Committee on Banking, Finance and Urban Affairs (March 5, 1979, p. 13, comment of Assistant Secretary Taylor that "If a market were disrupted, it might be very difficult to consummate the transaction. If the market were already disrupted because there had been an earthquake because the San Andreas Fault had broken up and down California, or if war had been declared, or if some major event of that kind had occurred, you might find the market would not be functioning very well.").

60 Committee on Banking, Finance and Urban Affairs (June 27 and 28, 1978, p. 19).

61 Committee on Banking, Finance and Urban Affairs (June 27 and 28, 1978, p. 20).

62 Committee on Banking, Finance and Urban Affairs (April 5, 1978, pp. 6-7, testimony of Assistant Secretary of the Treasury Paul Taylor).

63 "Delay on U.S. Debt Ceiling Hurts Treasury and Financial Markets," New York Times, March 31, 1979, p. 1 (reporting that "the Treasury arranged to borrow \$3 billion from the 
borrowings was not viewed as comparable to a national emergency or a temporary cash shortfall pending the arrival of tax receipts. Representative George Hansen of Idaho stated that he was "not particularly pleased" with the 1977 draw ${ }^{64}$ and, in a dissent to the House Banking Committee majority report on the 1979 bill renewing the exemption, Representative Ron Paul of Texas expressed the view that "in recent years, ... Treasury has been using the [exemption] not to finance a war, but to make end runs around Congress and the law.... Starting as a war power, the [exemption] has become a device that is used by the Treasury to ignore Congress and the law." 65

\section{Termination}

Following the March 1979 hearings, Congress renewed the \$5 billion exemption for two more years, but added a significant new limitation. The Act of June 8, 1979, eliminated the existing proviso to Section $14(\mathrm{~b})$ and added two new paragraphs to that subsection:

(3) In unusual and exigent circumstances and when authorized for renewable periods not to exceed thirty days, by the Board of Governors of the Federal Reserve System pursuant to an affirmative vote of not less than five members, to buy and sell, without regard to maturities, directly from or to the United States any bonds, notes, or other obligations which are direct obligations of the United States or which are fully guaranteed by the United States as to principal and interest. ...

(4) The aggregate amount of obligations acquired directly from the United States ... under the authority of this section which is held ... at any one time by the twelve Federal Reserve banks shall not exceed \$5,000,000,000. (Emphasis added.)

The act further provided that the prohibition on direct purchases would be restored in full and without any exemptions in two years.

Federal Reserve") and “Treasury's \$23.7 Billion in Issues Awaits Action in Congress on Lifting Debt Limit," Wall Street Journal, April 2, 1979, p. 33.

64 Committee on Banking, Finance and Urban Affairs (June 27 and 28, 1978, p. 2).

65 Committee on Banking, Finance and Urban Affairs (May 1, 1979, p. 7). 
The wording of the 1979 renewal suggests that Congress believed that the combination of short-term cash management bills and larger TT\&L balances provided an adequate safety net for virtually all Treasury operations and that authority for direct purchases was not needed outside of "unusual and exigent circumstances."

Treasury never again issued securities directly to the Federal Reserve and the authority of section 14(b)(3) expired in June 1981. 


\section{References}

Brockschmidt, Peggy. 1975. "Treasury Cash Balances." Federal Reserve Bank of Kansas City Monthly Review. July-August, pp. 12-20.

Chandler, Lester. 1958. Benjamin Strong, Central Banker. Brookings Institution: Washington D.C.

Committee on Banking and Currency. 1935. "Banking Act of 1935." Report No. 742, U.S. House of Representatives, $74^{\text {th }}$ Cong., $1^{\text {st }}$ Sess., April 19.

Committee on Banking and Currency. 1935. "Banking Act of 1935." Report No. 1007, U.S. Senate, $74^{\text {th }}$ Cong., $1^{\text {st }}$ Sess., May 13.

Committee on Banking and Currency. 1947. "Direct Purchases of Government Securities by Federal Reserve Banks." Hearing before the Committee on Banking and Currency. U.S. House of Representatives, $80^{\text {th }}$ Cong., $1^{\text {st }}$ Sess., March 3, 4, and 5.

Committee on Banking and Currency. 1947. "Direct Purchases of Government Securities by Federal Reserve Banks." Report No. 116, U.S. House of Representatives, $80^{\text {th }}$ Cong., $1^{\text {st }}$ Sess., March 10.

Committee on Banking, Finance and Urban Affairs. 1978. "Extending the Treasury-Federal Reserve Draw Authority." Hearing Before the Subcommittee on Domestic Monetary Policy of the Committee on Banking, Finance and Urban Affairs. U.S. House of Representatives, $95^{\text {th }}$ Cong., $2^{\text {nd }}$ Sess., April 5.

Committee on Banking, Finance and Urban Affairs. 1978. "Federal Reserve-Treasury Draw Authority." Hearings Before the Subcommittee on Domestic Monetary Policy of the Committee on Banking, Finance and Urban Affairs. U.S. House of Representatives, $95^{\text {th }}$ Cong., $2^{\text {nd }}$ Sess., June 27 and 28.

Committee on Banking, Finance and Urban Affairs. 1979. "Federal Reserve-Treasury Draw Authority." Hearing Before the Subcommittee on Domestic Monetary Policy of the Committee on Banking, Finance and Urban Affairs. U.S. House of Representatives, $96^{\text {th }}$ Cong., $1^{\text {st }}$ Sess., March 5.

Committee on Banking, Finance, and Urban Affairs. 1979. "Treasury Draw Authority Extension." Report No. 96-111, U.S. House of Representatives, $96^{\text {th }}$ Cong., $1^{\text {st }}$ Sess., May 1.

Committee of Conference. 1935. "Banking Act of 1935." Report No. 1822, U.S. House of Representatives, $74^{\text {th }}$ Cong., $1^{\text {st }}$ Sess., August 17.

Committee on the Judiciary. 1942. "Second War Powers Act." Statements in Executive Session on S. 2208. U.S. Senate, $77^{\text {th }}$ Cong., $2^{\text {nd }}$ Sess., January 19. 
Committee on the Judiciary. 1942. "Second War Powers Act, 1942," Hearings before the Committee on the Judiciary. U.S House of Representatives, $77^{\text {th }}$ Cong., $2^{\text {nd }}$ Sess., January 30 and February 2.

Garbade, Kenneth. 2012. Birth of a Market: The U.S. Treasury Securities Market from the Great War to the Great Depression. MIT Press: Cambridge, MA.

Harding, W.P.G. 1925. The Formative Period of the Federal Reserve System. Houghton Mifflin: Boston, MA.

Hendricks, Henry. 1933. The Federal Debt: 1919 - 1930. Mimeoform Press: Washington, D.C.

Hollander, Jacob. 1919. War Borrowing: A Study of Treasury Certificates of Indebtedness of the United States. Macmillan: New York, NY.

Lang, Richard. 1979. "TTL Note Accounts and the Money Supply Process," Federal Reserve Bank of St. Louis Review 61, no. 1 (October): 3-14.

Lovett, Joan. 1978. "Treasury Tax and Loan Accounts and Federal Reserve Open Market Operations." Federal Reserve Bank of New York Quarterly Review 3, no. 2 (Summer): 41-46.

McDonough, William. 1976. "New Policy Prompts Increased Defensive Operations by Federal Reserve.” Federal Reserve Bank of Dallas Business Review. March, pp. 8-12. 
Table 1. Treasury Cash Management Borrowings from Federal Reserve Banks During the First Year and a Half of World War I. 1918 Treasury Annual Report, p. 27.

\begin{tabular}{|c|c|c|}
\hline Date & Tenor & Amount \\
\hline & days & \$ millions \\
\hline \multicolumn{3}{|l|}{1917} \\
\hline Oct 11 & 7 & 100 \\
\hline Oct 16 & 2 & 10 \\
\hline Oct 17 & 1 & 20 \\
\hline Oct 29 & 2 & 20 \\
\hline Nov 15 & 4 & 150 \\
\hline Nov 19 & 1 & 150 \\
\hline \multicolumn{3}{|l|}{1918} \\
\hline Jan 11 & 4 & 50 \\
\hline Jan 15 & 1 & 50 \\
\hline Feb 8 & 5 & 70 \\
\hline Feb 21 & 5 & 80 \\
\hline Mar 8 & 3 & 40 \\
\hline May 10 & 1 & 75 \\
\hline May 17 & 4 & 40 \\
\hline May 31 & 1 & 60 \\
\hline Jun 11 & 7 & 10 \\
\hline Jun 11 & 9 & 15 \\
\hline Jun 28 & 1 & 195 \\
\hline Jun 29 & 3 & 190 \\
\hline Jul 12 & 1 & 15 \\
\hline Aug 8 & 5 & 20 \\
\hline Aug 8 & 8 & 10 \\
\hline Aug 8 & 12 & 15 \\
\hline Aug 16 & 1 & 15 \\
\hline Aug 26 & 1 & 10 \\
\hline Aug 26 & 8 & 20 \\
\hline Aug 26 & 11 & 10 \\
\hline Aug 26 & 15 & 20 \\
\hline Aug 26 & 18 & 10 \\
\hline Aug 26 & 22 & 19 \\
\hline Sep 3 & 1 & 45 \\
\hline Oct 7 & 1 & 25 \\
\hline Oct 7 & 3 & 10 \\
\hline Oct 7 & 8 & 5 \\
\hline Oct 25 & 3 & 185 \\
\hline Oct 25 & 1 & 18 \\
\hline Oct 25 & 3 & 35 \\
\hline Oct 25 & 1 & 18 \\
\hline Oct 28 & 1 & 160 \\
\hline Oct 29 & 2 & 10 \\
\hline
\end{tabular}


Table 2. Treasury Cash Management Borrowings from Federal Reserve Banks in 1926. 1929 Federal Reserve Board Annual Report, p. 71.

\begin{tabular}{lrr} 
Date & Tenor & Amount \\
\hline & days & \$ millions \\
Mar 15 & 1 & 209 \\
Mar 16 & 1 & 157 \\
Mar 17 & 1 & 99 \\
Mar 18 & 1 & 38 \\
& & \\
Jun 8 & 1 & 4 \\
Jun 9 & 1 & 4 \\
Jun 10 & 1 & 4 \\
& & \\
Jun 15 & 1 & 246 \\
Jun 16 & 1 & 142 \\
Jun 17 & 1 & 77 \\
Jun 18 & 1 & 23 \\
& & 192 \\
Sep 15 & 1 & 73 \\
Sep 16 & 1 & 7 \\
Sep 17 & 1 & \\
Dec 15 & 1 & 70 \\
Dec 16 & 1 &
\end{tabular}


Table 3. Treasury Cash Management Borrowings from Federal Reserve Banks in 1927. 1929 Federal Reserve Board Annual Report, p. 71.

\begin{tabular}{|c|c|c|}
\hline Date & Tenor & Amount \\
\hline & days & \$ millions \\
\hline Mar 15 & 1 & 252 \\
\hline Mar 16 & 1 & 178 \\
\hline Mar 17 & 1 & 176 \\
\hline Mar 18 & 1 & 79 \\
\hline Mar 19 & 2 & 48 \\
\hline Mar 21 & 1 & 16 \\
\hline Mar 22 & 1 & 9 \\
\hline Mar 23 & 1 & 3 \\
\hline Jun 15 & 1 & 185 \\
\hline Jun 16 & 1 & 45 \\
\hline Jun 17 & 1 & 16 \\
\hline Jun 18 & 2 & 7 \\
\hline Sep 15 & 1 & 197 \\
\hline Sep 16 & 1 & 92 \\
\hline Sep 17 & 2 & 54 \\
\hline Nov 15 & 1 & 90 \\
\hline Nov 16 & 1 & 165 \\
\hline Nov 17 & 1 & 215 \\
\hline Nov 18 & 1 & 135 \\
\hline Nov 19 & 2 & 157 \\
\hline Nov 21 & 1 & 46 \\
\hline Nov 22 & 1 & 62 \\
\hline Nov 23 & 2 & 81 \\
\hline Nov 25 & 1 & 21 \\
\hline Nov 26 & 2 & 27 \\
\hline Nov 28 & 1 & 38 \\
\hline Nov 30 & 1 & 2 \\
\hline Dec 1 & 1 & 4 \\
\hline Dec 2 & 1 & 15 \\
\hline $\operatorname{Dec} 3$ & 2 & 27 \\
\hline Dec 5 & 1 & 38 \\
\hline Dec 6 & 1 & 47 \\
\hline Dec 7 & 1 & 50 \\
\hline Dec 8 & 1 & 54 \\
\hline Dec 9 & 1 & 58 \\
\hline Dec 10 & 2 & 57 \\
\hline Dec 12 & 1 & 54 \\
\hline Dec 13 & 1 & 50 \\
\hline Dec 14 & 1 & 40 \\
\hline Dec 15 & 1 & 198 \\
\hline Dec 16 & 1 & 107 \\
\hline Dec 17 & 2 & 57 \\
\hline Dec 19 & 1 & 10 \\
\hline
\end{tabular}


Table 4. Summary of Treasury Cash Management Borrowings from Federal Reserve Banks, 1942 to 1979. Committee on Banking, Finance, and Urban Affairs (June 27 and 28, 1978, p. 14) and 1981 Board of Governors Annual Report, p. 221.

\begin{tabular}{|c|c|c|c|c|}
\hline Year & $\begin{array}{r}\text { Days } \\
\text { Utilized } \\
\end{array}$ & $\begin{array}{r}\text { Maximum amount } \\
\text { borrowed } \\
\text { on any one day } \\
\end{array}$ & $\begin{array}{r}\text { Number of } \\
\text { separate } \\
\text { times used } \\
\end{array}$ & $\begin{array}{r}\text { Maximum number of } \\
\text { days in } \\
\text { any one use }\end{array}$ \\
\hline & & \$ millions & & \\
\hline 1942 & 19 & 422 & 4 & 6 \\
\hline 1943 & 48 & 1,302 & 4 & 28 \\
\hline 1944 & 0 & & & \\
\hline 1945 & 9 & 484 & 2 & 7 \\
\hline 1946 & 0 & & & \\
\hline 1947 & 0 & & & \\
\hline 1948 & 0 & & & \\
\hline 1949 & 2 & 220 & 1 & 2 \\
\hline 1950 & 2 & 180 & 2 & 1 \\
\hline 1951 & 4 & 320 & 2 & 2 \\
\hline 1952 & 30 & 811 & 4 & 9 \\
\hline 1953 & 29 & 1,172 & 2 & 20 \\
\hline 1954 & 15 & 424 & 2 & 13 \\
\hline 1955 & 0 & & & \\
\hline 1956 & 0 & & & \\
\hline 1957 & 0 & & & \\
\hline 1958 & 2 & 207 & 1 & 2 \\
\hline 1959 & 0 & & & \\
\hline 1960 & 0 & & & \\
\hline 1961 & 0 & & & \\
\hline 1962 & 0 & & & \\
\hline 1963 & 0 & & & \\
\hline 1964 & 0 & & & \\
\hline 1965 & 0 & & & \\
\hline 1966 & 3 & 169 & 1 & 3 \\
\hline 1967 & 7 & 153 & 3 & 3 \\
\hline 1968 & 8 & 596 & 3 & 6 \\
\hline 1969 & 21 & 1,102 & 2 & 12 \\
\hline 1970 & 0 & & & \\
\hline 1971 & 9 & 610 & 1 & 7 \\
\hline 1972 & 1 & 38 & 1 & 1 \\
\hline 1973 & 10 & 485 & 3 & 6 \\
\hline 1974 & 1 & 131 & 1 & 1 \\
\hline 1975 & 16 & 1,042 & 4 & 7 \\
\hline 1976 & 0 & & & \\
\hline 1977 & 4 & 2,500 & 1 & 4 \\
\hline 1978 & 0 & & & \\
\hline 1979 & 1 & 2,600 & 1 & 4 \\
\hline
\end{tabular}


Table 5. Short-Term Cash Management Bills, 1976 to 1979. Treasury Annual Reports and Treasury Bulletin.

\begin{tabular}{|c|c|c|c|c|}
\hline Announcement & Auction & Settle & Tenor & Amount \\
\hline & & & days & $\$$ billions \\
\hline \multicolumn{5}{|l|}{1975} \\
\hline Aug 6 & Aug 7 & Aug 8 & 18 & 1.00 \\
\hline Sep 3 & Sep 4 & Sep 5 & 13 & 0.80 \\
\hline Sep 3 & Sep 4 & Sep 5 & 20 & 0.70 \\
\hline Dec 4 & Dec 5 & Dec 8 & 10 & 0.60 \\
\hline Dec 4 & Dec 5 & Dec 8 & 18 & 0.60 \\
\hline \multicolumn{5}{|l|}{1976} \\
\hline Apr 5 & Apr 7 & Apr 8 & 14 & 2.50 \\
\hline Jun 4 & Jun 7 & Jun 8 & 9 & 2.00 \\
\hline \multicolumn{5}{|l|}{1977} \\
\hline Mar 28 & Apr 1 & Apr 6 & 15 & 4.50 \\
\hline May 31 & Jun 3 & Jun7 & 9 & 2.00 \\
\hline Aug 31 & Sep 1 & Sep 6 & 9 & 0.90 \\
\hline Aug 31 & Sep 1 & Sep 6 & 16 & 0.90 \\
\hline Nov 3 & Nov 4 & Nov 7 & 8 & 2.50 \\
\hline \multicolumn{5}{|l|}{1978} \\
\hline Mar 1 & Mar 3 & Mar 8 & 43 & 3.00 \\
\hline Mar 28 & Mar 30 & Apr 3 & 24 & 6.00 \\
\hline May 26 & Jun 1 & Jun 2 & 20 & 6.00 \\
\hline \multicolumn{5}{|l|}{1979} \\
\hline Feb 23 & Feb 27 & Mar 2 & 48 & 4.00 \\
\hline Apr 2 & Apr 3 & Apr 3 & 23 & 6.00 \\
\hline Apr 2 & Apr 3 & Apr 4 & 15 & 4.00 \\
\hline Apr 2 & Apr 5 & Apr 6 & 76 & 3.00 \\
\hline May 29 & May 31 & Jun 4 & 15 & 5.00 \\
\hline May 29 & Jun 4 & Jun 5 & 16 & 4.50 \\
\hline Aug 28 & Aug 30 & Sep 4 & 14 & 2.00 \\
\hline
\end{tabular}

